\title{
Investigating the Brand Loyalty of Domestic Cosmetic in an Emerging Market
}

\author{
Norizan Mohd Kassim ${ }^{1 *}$, Nurfatihah Akmal Binti Jamaludin ${ }^{2}$, Zullina Hussain Shaari ${ }^{3}$ \\ ${ }^{1}$ Department of Business Management College of Economics, Management and Information Systems, University of Nizwa, Oman \\ ${ }^{2,3}$ Management and Humanities Department, Universiti Teknologi PETRONAS Malaysia
}

\begin{abstract}
The cosmetic industry in emerging economies such as Malaysia shows vast growth. However, fierce competition has forced domestic cosmetic brands to be more competitive. Brand loyalty is one of the key aspects of management to retain the competitive advantages of the market. Thus, this research would like to investigate the factors that led to the brand loyalty of the domestic cosmetics brand in Malaysia. There are four independent variables in this study, namely brand price, brand perceived value, brand satisfaction, and brand trust, while brand loyalty is a dependent variable. A correlation study was conducted to determine whether there is a positive relationship between the dependent variable and the independent variable. The purpose of this study is twofold: First, to examine the level of loyalty of domestic consumer brands; second, to investigate the relationship between brand prices, brand satisfaction, brand trust, and brand perceive value to the brand loyalty of cosmetic brand. A survey was conducted to measure these variables. A total of 200 useable questionnaires were collected from a commercial hub in Malaysia. Descriptive and correlation analysis were used to investigate the level of loyalty and to test the relationship between these variables.
\end{abstract}

Keywords-brand loyalty, brand price, brand trust, brand perceive value, brand satisfaction, domestic cosmetic brand.

\section{INTRODUCTION}

One of the promising industries in an emerging market that creates high revenue and profitability is the cosmetic industry (Hassali et al., 2015). The Asia Pacific cosmetics industry's market value has increased to more than US\$ 70 billion, that is, the second highest in Western Europe (Asian cosmetic, 2008). However, since the Muslims comprise $20 \%$ of the world's population, they have begun to push the traditional cosmetics industry to listen to their voices and meet their needs, as well as to increase demand for Shariah-compliant goods which are labelled as halal cosmetic and personal care product. Halal, in general, refers to things or actions which are permitted under Shariah (Islamic) law. The definition covers all aspects of production within the context of Halal cosmetics, including the procurement of Halal ingredients and the use of permitted substances - all shall be made, processed, packaged and distributed in accordance with the requirements of the Shariah. Islam requires Muslims to abide by its specific guidelines and standards for goods and services consumption; (Al-Khatib et al., 1995; Rice, 1999).

The demand for halal products is a new phenomenon in the global cosmetic industry. This is due to the increased awareness among the growing global Muslim population of the ingredients of personal care and cosmetic products. This new trend in the global cosmetics market is faith-based and may be reflected in the recent shift in the global scenario. The total size of the Halal cosmetics market is estimated to be between USD 5-14 billion (Hassali et al., 2015).

For the halal pharmaceutical and cosmetics industries, Malaysia is one of the top 10 producers in the world (Ngah et al., 2018). In the nation, a brand that introduces new products must re-apply for the halal certification (Low, 2017). This indirectly suggests that the majority of domestic cosmetic brands in Malaysia is Halal. Halal skincare or cosmetic products mean that they are free from animal-derived ingredients (e.g., animal fats, placenta, etc.) and materials that are harmful to health and have not

${ }^{*}$ Corresponding Author: Nkassim@unizwa.edu.om 
been processed using impurity-contaminated instruments such as blood, urine and faecal products. Some halal-certified beauty products also carry vegan, organic, cruelty-free or ethical labels and certifications in accordance with industry standards.

Total Muslim consumer spending in Malaysia is 31.62 million (2017), with an increasing number of consumers concerned about the Halal cosmetics they consume (Hassali et al., 2015). However, the fierce competition between import brands in Malaysia has forced domestic cosmetic brand to adopt a better strategy to survive and remain on the market. It is even more intense as companies make value for the customer to gain market share, which is only possible by building customer loyalty to the brand. Based on the market share of the cosmetic brand in Malaysia, the import brands still dominated the market (Swidi et al., 2010). According to Cseres (2005) market share is a measure of the consumers' preference for a product over other similar products. This has shown that consumer preference over domestic cosmetic brands is lower compared to imported brands in Malaysia, even though most Malaysia's population is Muslim. According to Akdeniz et al., (2013) consumer preferences for imported products are always related to better quality and high reputation, even though Halal status is uncertain. Therefore, in order to enhance the value of domestic cosmetic brands, a better view should be highlighted.

Brand loyalty is one of the key aspects of management in maintaining the competitive advantages of the market and give high values to the brand. Moreover, based on Rosenberg and Czepial (1984), they claimed that marketing costs should be reduced if the organization has a loyal customer. Furthermore, the cost of retaining existing customers is approximately six times lower than the cost of attracting new customers. The other factor that contributes to the significant impact of brand loyalty is that loyal customers spend more money, compare non-loyal customers (O'Brien \& Jones, 1995) and act as primary supporters of the brand by engaging in a positive word of mouth (Oliver \& Swan, 1999). However, based on past research between 2009 and 2019, there is no research on the factors that lead to brand loyalty in domestic cosmetics brands among Muslim consumers. Thus, this research would like to fill the gap. The purpose of this study is to investigate the factors that led to the brand loyalty of the domestic cosmetics brand.

In addition, most of the brand loyalty research for cosmetic products focuses on utilitarian attributes to maintain consumer loyalty and very restricted research has directly link to hedonic attributes. However, after accessing past research, utilitarian attributes alone do not significantly influence consumer loyalty. It is important to deliver an adequate balance between utilitarian and hedonic attributes to maintain consistency of customer loyalty to the brand in the long run (Gentile et al., 2007). Thus, this research complementary existing researcher by examining utilitarian (brand price) and hedonic attribute (brand perceive value, brand trust and brand satisfaction) towards brand loyalty.

\section{LITERATURE REVIEW}

\section{BRAND LOYALTY}

Brand identifies and distinguishes the sellers. Brand building creates incredible value for companies and businesses. In addition, it is important to promise the seller to consistently deliver a specific set of benefits, features and services to buyers. Best trademarks provide a guarantee of quality (Kotler 2010). The best branding we've got today is based on a solid idea. The best advertising brands are remarkably creative in helping them to break through the wall of indifference to create a brand list of heat and products for people. Brand loyalty helps the organization survive on the market (Ahmed, 2014).

Based on the same study, the analyst also indicated that consumers already prefer the company according to their preferences, including product characteristics, brand image awareness and marketplace. Consumer satisfaction arises when customers make repeated purchases over a long period of time (Sidek \& Yahyah, 2008) Loyalty shown by consistent purchases by consumers is the key to the competitiveness of the company (Heim et al., 2001)

This study focuses on four factors that influence brand loyalty. These factors adapted by (Omanga, 2010). The factors include brand price, brand perceive value, brand satisfaction, and brand trust. According to several research, these factors have a significant relationship towards brand loyalty. If the product price is consistent, the customer feels motivated to repeat purchase of the product (Schindler, 1998). According to Chandon, Wansink and Laurent (2010), however, consumers' past experiences with a retailer will have an impact on their assessment of the price charged by a retailer.

Brand trust impacts brand loyalty as well. Trust is necessary for developing and maintaining long-term relationships, particularly in the business environment (Mittal, 1994). Brand loyalty has been characterised as either a behavioural intention toward the brand or a certain pattern of purchase behaviour, or both, as a result of brand trust (Sidek \& Yahyah, 2008). It continued by stating that brand trust is critical in determining the relationship between overall consumer satisfaction and brand 
loyalty. Zbooja and Voorhes (2006) discovered that brand trust acts as a moderator in the relationship between satisfaction and brand loyalty in the retail business. It establishes that a customer's prior interaction with a product has an effect on their level of satisfaction with that product, resulting in brand loyalty (Bowden, 2009).

Whereas according to Mansor (2010), the goal of providing value to consumers consistently and more efficiently than rivals is to provide and attract highly satisfied consumers. Brand satisfaction has been studied extensively as a predictor of customer loyalty (Usman 2010). This overall satisfaction had a strong positive effect on the intentions of brand loyalty across a broad range of product and service categories (Thaler, 1985). It is an important factor in the company's long-term relationship with customers. In addition, the brand's perception of value may be linked to service and product quality (Mansor, 2010). According to Omanga (2010) there have a positive relationship of brand loyalty and perceive value.

\section{BRAND PRICE}

The average consumer's first and most important factor, according to Cadogan and Foster (2000), is brand pricing. They contended that because consumers with high market loyalty are prepared to pay a premium for their favourite brand, cost has no bearing on their purchasing decision. Consumers, on the other hand, are so confident in the quality and value of their own products that they compare and evaluate pricing against competitors' brands (Keller, 2003).Furthermore, by aligning pricing to perceived costs and values, consumer loyalty can be increased. When the perceived value of a product exceeds its cost, people may be more likely to acquire it. According to Yoon and Kim (2000), loyal customers are willing to pay a premium even if the price has grown since the perceived cost is very high, and they prefer to pay a higher price to avoid any improvement. Long-term service loyalty relationships make loyal customers more willing to accept costs, because loyalty discourages consumers from comparing rates to other items through shopping around. Price has increasingly become the focus of consumer judgments on the value of the offer as well as on their overall assessment of the retailer (De Ruyter, Wetzels \& Van Birgelen, 1999).

Furthermore, in studying consumer behaviour in terms of pricing, the customer's assessment of price quality is crucial. This is due to the fact that customers frequently establish a standard pricing for a product and regard a certain sort of product to be a reasonable price. The regular price that the customer anticipates will then be used to compare pricing to the skin care company's other brands. Normal commodity prices, also known as reference prices, are often influenced by the values that consumers recall from the past, according to Ash and Wolfe (2011).

When a customer pays for a commodity rather than simply viewing or experiencing it in a store, the prior price has the greatest impact on the current price. Customers frequently confuse the previous sale price with the current one. The most recent purchase price has the effect of prompting the customer to refer to it and compare the pricing of old and new skin care products. If the price remains the same as before, the customer will continue to purchase the skin care product. Manufacturers sometimes increase the price of the skin care product by improving the product packaging and the size of the product. When moving down this road, loyal consumers are likely to repurchase even though they must pay a premium price because the perceived cost is very high and choose to pay a higher price to reduce the possibility of any adjustment (Bruner, 2000).

Brand price is one of the key tools every store must positively or negatively influence customers. Customers differ widely, some being more price sensitive and others more cost oriented. According to Omanga (2010) he stated that brand price has a strong influence on brand loyalty as the results show the positive relationship between brand price and brand loyalty towards the cosmetic products.

\section{BRAND SATISFACTION}

Prior research has placed a high premium on brand satisfaction. The majority of them stated that brand satisfaction and brand loyalty are positively related. Satisfaction with a brand can be defined as when a company meets or exceeds a set of client expectations. According to Gerpott, Rams, and Schindler (2011), a consumer's level of satisfaction is determined by the quality of the brand qualities given by a company. The contentment with a brand that contributes to a company's future profitability (Moore, Karl, Lewis \& David, 1998). Additionally, Moore et al. (1998) argued that brand loyalty is critical in order to please consumers. Unsatisfied consumers of a firm do not hesitate to switch brands and will do so immediately upon becoming dissatisfied with the brand itself (Lin \& Wu, 2011). Additionally, low-quality services can result in discontent. According to Cronin, Brady, and Hult (2000), brand satisfaction is determined by the company's ability to provide high-quality service and products, and they describe a low-quality service as one that does not meet the need.

Increased brand satisfaction has been demonstrated to have a direct effect on a company's market share, resulting in increased profitability, good recommendations, and decreased marketing expenses (Klein et al., 1993), as well as a major effect on the 
company's image and survival (Aspinall \& Reichheld, 1993). He also notes that despite several attempts to quantify and explain brand happiness, no consensus on its definition appears to exist. Apart from that, brand satisfaction is often described as an evaluation of a product or service following its usage (Bitner \& Hubbert, 1994). It resulted in a finding indicating a process in which expectations are compared to perceptions of performance both during and after the consumption experience (Oliver, 2011). As a result, it is critical for the business to exceed the customer's expectations in order to retain their business.

According to Innamullah (2012), brand satisfaction is a necessary component of a company's retention strategy. However, Hamza (2011) claimed in his study that it would be unreasonable to expect unsatisfied customers to maintain a long-term engagement with the organisation. Variation in the quality and value of the customer's products and services affects the brand's satisfaction and brand loyalty. (Fifty-year-old Mansor). According to Nadome (2014), brand satisfaction is measured internally to compensate for human resources, to monitor performance, and to allocate cash, as well as externally to happy customers. Customers, public policymakers, competitors, and investors will all benefit from brand satisfaction (Lin \& Wu, 2011).

Brand satisfaction can result in brand loyalty, if the link is significant and positive. Omanga (2010) asserted that brand satisfaction and brand loyalty are positively correlated. Satisfaction with a brand can be defined as when a company meets or exceeds a set of customer expectations. (2009) (Omanga, 2010). According to Gerpott et al., (2011), a consumer's level of satisfaction is determined by the type of the brand features provided by a business. Satisfaction with a brand might help a business earn more money in the future (Moore et al., 1998). It is critical to satisfy customers in order to retain them. Brand satisfaction does have a favourable effect on an organization's profitability.

\section{BRAND PERCEIVE VALUE}

Perceived value has recently piqued the interest of marketing managers and researchers as one of the most powerful indicators of brand satisfaction and loyalty. Perceived value is a relatively new area of study that is gaining popularity among marketers. Based on equity theory, perceived value considers the proportion of a consumer's outcome or input to that of a service provider. (Oliver, 2011). This fascination originates mostly from the importance that today's businesses have on creating value for their various target audiences. Customer satisfaction and intents to refer and repurchase are influenced by perceived value not just during the pre-buy stage, but also after the purchase (Parasuraman \& Grewal, 2000).

The subjective concept of brand perceived value might be defined as follows: It can be divided into many scenes that vary depending on the consumer (Rizwan, 2013), the culture (Assael, 2010), and the moment (Ravald \& Gronroos, 1996). This last appreciation views perceived value as a dynamic variable that can be felt prior to purchase, during purchase, during use, and after use. The valuations made for each of these moments were different (Gardial, Clemons, Woodruff, Schumann, \& Burns, 1994).

Brand perceived value has been demonstrated to be a strong predictor of brand loyalty, according to Cronin, et al., (2000). Furthermore, Ravald and Gronroos (1996) claim that value is a crucial component of relationship marketing and one of the most effective competitive strategies. Perceived value is a key metric for achieving a competitive advantage, and it's also a key predictor of brand loyalty (Beckman \& Crompton, 1991). However, according to Woodruff (1997), measures of received (attribute) value are antecedents to total brand satisfaction in his study, and these measures have been shown to connect well with buying behaviour such as word-of-mouth and purchase intention.

The most crucial factor is that perceived worth can affect a company's profit year after year. According to Eduardo (2008), organisations attempting to gain consumer loyalty should concentrate on brand perceived value first. It will assist the company in maximizing profits and earning revenue from the perceived worth of their brand.

\section{BRAND TRUST}

Trust has been seen as a key element of the brand's success. This is described as "the average consumer's willingness to rely on the brand's ability to fulfill its stated purpose" (Chaudhuri \& Holbrook, 2001, page no.) More precisely, trust involves consumer perceptions of goods, brands, services or salespeople, and the establishment where the products or services are purchased and sold (Belanger, 2002). On the other hand, personal psychologists' confidence as an individual trait, social psychologists considers trust as a transaction-specific expectation and to the person with whom a transaction is being made (Lewicki \& Bunker, 1995).

Indeed, trust has been seen as a vital element in a good relationship (Parasuraman, 1980). He points out that customers need to feel safe in their interactions with suppliers and also need to be assured that their relationship is confident that they will be able to trust their suppliers. It is a significant feature or factor in the creation of quality relationships formed through the process of 
creating and sustaining commitments, where customers have assurances that the products they buy are of high quality and with frequent transactions in return.

Furthermore, previous studies have shown that brand loyalty is a consequence of trust (references) because, for example, if customers have confidence in and satisfaction with such skin care cosmetic products in a skin care category, there will be a high probability for them not to turn to another skin care product. According to Omanga (2010), brand trust has a positive impact on brand loyalty.

\section{Conceptual Framework AND Hypothesis}

Table 1: Research Hypothesis

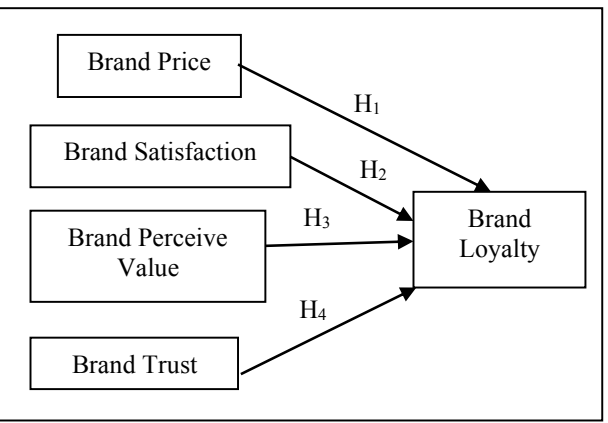

\begin{tabular}{|l|l|}
\hline & \multicolumn{1}{|c|}{ Hypotheses } \\
\hline $\mathrm{H}_{1}:$ & $\begin{array}{l}\text { In the domestic cosmetics industry, there is a strong } \\
\text { association between brand price and brand loyalty. }\end{array}$ \\
\hline $\mathrm{H}_{2}:$ & $\begin{array}{l}\text { In the domestic cosmetics industry, there is a strong } \\
\text { association between brand satisfaction and brand } \\
\text { loyalty. }\end{array}$ \\
\hline $\mathrm{H}_{3:}$ & $\begin{array}{l}\text { In the domestic cosmetics industry, there is a strong } \\
\text { association between brand perceive value and brand } \\
\text { loyalty. }\end{array}$ \\
\hline $\mathrm{H}_{4:}: \begin{array}{l}\text { In the domestic cosmetics industry, there is a strong } \\
\text { association between brand trust and brand loyalty. }\end{array}$ \\
\hline
\end{tabular}

Figure 1: Research Framework adapted from Omanga (2010)

\section{METHODOLOGY}

This study was conducted independently of the researcher in one of Malaysia's commercial hubs. Local cosmetic consumers served as the study's unit of analysis, and due to time constraints, a convenient sampling approach was used (Saunders et al., 2009). 370 questionnaire sets were distributed using Roscoe's (1975) sample size guidelines. The questionnaire is primarily concerned with pricing and brand satisfaction.

The analyses were conducted using the SPSS software system. The data were analysed using descriptive analysis, correlation analysis, and regression analysis. We conducted reliability and validity tests on the survey instrument. Cronbach's alpha was used to determine consistency, and correlations analysis was used to determine validity.

\section{Data Analysis}

Table 2: Description of Respondent's Demographic Profiles

\begin{tabular}{|c|c|c|c|c|}
\hline Label & Options & Frequency & Percent (\%) & Rank \\
\hline \multirow{4}{*}{ Age } & $12-20$ years old & 33 & 16.5 & 3 \\
\cline { 2 - 5 } & $21-30$ years old & 89 & 44.5 & 1 \\
\cline { 2 - 5 } & $31-40$ years old & 69 & 34.5 & 2 \\
\cline { 2 - 5 } & Others & 9 & 4.5 & 4 \\
\hline \multirow{4}{*}{ Citizenship } & Yes & 200 & 100.0 & 2 \\
\cline { 2 - 5 } & No & 0 & 0.0 & 1 \\
\hline \multirow{3}{*}{ Profession } & Student & 73 & 31.5 & 2 \\
\cline { 2 - 5 } & Employed & 28 & 14.0 & 3 \\
\cline { 2 - 5 } & Housewife & 16 & 8.0 & 4 \\
\cline { 2 - 5 } & Part time employed & & & \\
\hline
\end{tabular}




\begin{tabular}{|c|c|c|c|c|}
\hline \multirow{3}{*}{ Experience } & Yes & 200 & 100.0 & 1 \\
\cline { 2 - 5 } & No & 0 & 0 & 0 \\
\hline \multirow{3}{*}{ Frequency } & Once a year & 76 & 38.0 & 1 \\
\cline { 2 - 5 } & Twice a year & 70 & 35.0 & 2 \\
\cline { 2 - 5 } Total Spending Year & Three times a year & 31 & 25.5 & 3 \\
\cline { 2 - 5 } & Others & 34 & 1.5 & 4 \\
\cline { 2 - 5 } & RM 50 & 43 & 21.5 & 3 \\
\cline { 2 - 5 } & RM 100 & 33 & 16.5 & 4 \\
\cline { 2 - 5 } & RM 150 & 37 & 18.5 & 2 \\
\cline { 2 - 5 } & RM 200 & 31 & 15.5 & 5 \\
\cline { 2 - 5 } & RM 250 & 22 & 11.0 & 6 \\
\hline
\end{tabular}

Table 3.1 shows the frequency analysis of demographic factors for a total of 200 respondents participating in this survey. Based on the analysis, 100 per cent are customers of domestic cosmetic brands. In terms of age, $16.5 \%$ ( 33 respondents) were between 12 to 20 years old. $44.5 \%$ ( 89 respondents) were between 21 to 30 years old. $34.5 \%$ ( 69 respondents) were between 31 to 40 years old and $4.5 \%$ ( 9 respondents) were from others which was more than 40 years old. Generally, the age between 21 and 30 years of age is the highest percentage of respondents in this study and the lowest is the other, which is only $4.5 \%$ ( 9 respondents).

In this study, all the respondents were citizenship which was $100 \%$ answered they are citizen in Malaysia. The profession of total respondents also gives the majority on student which indicated the percentage of $41.5 \%$ followed by employed $36.5 \%$, housewife $14 \%$. The lowest was part time employed which give $8 \%$.

Statistic showed that all the respondents were all experienced bought the domestic cosmetic brand product. In addition, it shows that most respondents were buying the product once a year, giving the highest percentage of $38 \%$. It was followed twice a year, three times a year, and the rest. Total expenditure statistics provide the highest percentage, which is $21.5 \%$ for RM 100 and the lowest is $11 \%$ for RM 300 per year.

Table 3: Summary of Reliability Each Variable

\begin{tabular}{|c|c|c|c|}
\hline Variables Item & No of items & $\begin{array}{c}\text { Value of Cronbach's } \\
\text { Alpha }\end{array}$ & Remarks* $^{*}$ \\
\hline Brand Loyalty & 12 & 0.941 & Good \\
\hline Brand Price & 3 & 0.813 & Good \\
\hline Brand Perceived Value & 2 & 0.719 & Excellent \\
\hline Brand Satisfaction & 5 & 0.914 & Excellent \\
\hline Brand Trust & 7 & 0.933 & \\
\hline
\end{tabular}

The results of the reliability test for each variable are shown in Table 3.3. The results show that all variables are reliable, which means that most respondents understood the question

Table 4: Descriptive Analysis of Brand Loyalty

\begin{tabular}{|c|c|c|c|}
\hline \multicolumn{4}{|c|}{ Descriptive Statistic } \\
\hline & $\mathrm{N}$ & Mean & Std. Deviation \\
\hline Brand Loyalty & $\mathbf{2 0 0}$ & $\mathbf{4 . 2 8}$ & $\mathbf{. 6 7 6}$ \\
\hline
\end{tabular}




\begin{tabular}{|c|l|l|l|}
\hline Brand Price & 200 & 4.2117 & .72074 \\
\hline Brand Perceive Value & 200 & 4.3575 & .72877 \\
\hline Brand Satisfaction & 200 & 4.3370 & .69241 \\
\hline Brand Trust & 200 & 4.3693 & .66349 \\
\hline Valid N (Listwise) & 200 & & \\
\hline
\end{tabular}

The descriptive analysis for each variable is shown in Table 3.2. The result shows that all items have received a higher score. This indicated that most consumers have a high level of agreement on each variable.

Table 5: Pearson Correlation

\begin{tabular}{|l|l|l|l|l|l|}
\hline & Brand Loyalty & Brand Price & Brand Perceive Value & Brand Satisfaction & Brand Trust \\
\hline Brand Loyalty & 1 & & & & \\
\hline Brand Price & $0.811^{* *}$ & 1 & & & \\
\hline Brand Perceive Value & $0.734^{* *}$ & $0.605^{* *}$ & 1 & & \\
\hline Brand Satisfaction & $0.741^{* *}$ & $0.697^{* *}$ & $0.622^{* *}$ & 1 & \\
\hline Brand Trust & $0.752^{* *}$ & $0.620^{* *}$ & $0.588^{* *}$ & $0.667^{* *}$ & 1 \\
\hline
\end{tabular}

** Correlation is significant at the 0.01 level (1-tailed)

Table 3.4 shows Pearson correlation analysis between dependent variable (brand loyalty) and independent variables (brand price, brand perceive value, brand satisfaction and brand trust). The result shows that there is a very strong relationship between brand loyalty and brand price, as shown $(0.811)$ followed by brand trust $(0.752)$, brand satisfaction $(0.741)$ and lastly brand perceive value $(0.734)$. Therefore, this means all hypothesis are being accepted.

\section{Conclusion}

The research is guided by two distinct objectives. Specifically, to ascertain the amount of brand loyalty among domestic consumer brands. According to the descriptive analysis, consumers have a high level of devotion to domestic cosmetic brands. Second, to examine the relationship between brand price, brand satisfaction, brand trust, brand perceives value in to the brand loyalty. As a result of the findings, it is clear that brand price, brand satisfaction, brand trust, and brand perceive value, all have a positive correlation with brand loyalty. Thus, all hypotheses are accepted.

Additionally, the findings indicate that domestic cosmetic brands must pay attention to utilitarian (brand pricing) and hedonic (brand perceived value, brand satisfaction, and brand trust) values in order to sustain customer loyalty, as all of these elements have a favourable effect on brand loyalty..

\section{RECOMMENDATION}

Marketers benefit from this research since it identifies factors that influence brand loyalty. As a result, it indicates that pricing, trust, perceived value, and satisfaction all influence brand loyalty. In terms of brand price, brands should remain competitive in order to dissuade people from switching to the brand. Meanwhile, to increase brand trust, the brand might advertise actively to guarantee that the consumer is aware of and trusts the brand. 2007 (Luk et al., 2008). Additionally, domestic cosmetic brands must maintain the highest possible product quality, as this may impact consumer happiness and perceived brand value (Saleem et al., 2015).

\section{REFERENCES}

1. (2008) ASEAN definition of cosmetics and illustrative list by category of cosmetic products.

2. (2014) Cosmetics and toiletries market overviews, Compiled by U.S. Commercial Service Hong Kong, The U.S. Commercial Service. 
3. (2009) Guidelines for Control of Cosmetics Products in Malaysia, National Pharmaceutical Control Bureau, Ministry of Health, Malaysia.

4. (2014) Cosmetics and toiletries market overviews, Compiled by U.S. Commercial Service Hong Kong, The U.S. Commercial Service.

5. (2014) Cosmetics Markets in 5 ASEAN Countries: Key Research Findings, Yano Research Institute

6. 2008) ASEAN definition of cosmetics and illustrative list by category of cosmetic products.

7. Aaker, D. A. (1991). Managing brand equity. New York: Free Press.

8. Aaker, D. A. (1996). Measuring brand equity across products and markets. New York: Free Press.

9. Aaker, J. L. (1997). Dimensions of brand personality. Journal of Marketing Research, 34, 347-356. http://dx.doi.org/10.2307/3151897

10. Agarwal, R., Grassl, W., and Pahl, J. (2012). Meta-SWOT: Introducing a new strategic planning tool. Journal of Business Strategy, 33(2), pp. 12-21.

11. Ahmed, Z. (2014). Effect of brand trust and customer satisfaction on brand. Journal. of Sociological Research, 306326

12. Akdeniz, B., Calantone, R. J., \& Voorhees, C. M. (2013). Effectiveness of marketing cues on consumer perceptions of quality: The moderating roles of brand reputation and third-party information. Psychology \& Marketing, 30(1), 76-89.

13. Al-Khatib, J. A., Dobie, K., \& Vitell, S. J. (1995). Consumer ethics in developing countries: an empirical investigation. Journal of Euromarketing, 4(2), 87-109.

14. Allen, P., Bennet, K. \& Heritage, B. (2014). SPSS Statistics Version 22: A Practical Guide. Australia: Cengage Learning Australia.

15. Arora, A. (2013). Brand loyalty: a multidimensional concept. International Journal of Science, Engineering and Technology Research (IJSETR) 2(2), 122-360.

16. Ash, J.,\& Wolfe, B.P. (2011). Forging relationships with services: The antecedents that have an impact on behavioral outcomes in the life insurance industry. Journal of Financial Services Marketing, 8(4), 3-14.

17. Aspinall, K., \& Reichheld, F. (1993). Building high-loyalty Business systems. Journal of Retail Banking, 15(4), 9-21

18. Assael, H. (2010), Consumer Behavior and Marketing Action, 6th edition, Ohio: South Western College Publishing.

19. Atilgan, E., Aksoy. S.K., \& Akinci, S. (2005). Determinants of The brand equity- a verification approach in the beverage industry in Turkey, Marketing Intelligence \& Planning, 23(3), 237-248.

20. Backman, S.J., \& Crompton, J.L. (1991). The usefulness of selected variables for predicting activity loyalty, Journal of Leisure Science, 205-220.

21. Belanger, W.J. (2002). Integrated marketing communications. In Marketing 482-506. New York: McGraw Hill.

22. Bitner, M. J., \& Hubbert, A. R. (1994). Encounter satisfaction Versus overall Satisfaction versus quality. Service quality: New directions in theory and practice, $72-94$.

23. Bowden, J. L. (2009). The Process of Customer Engagement: A Conceptual Framework, Journal of Marketing Theory and Practice, 17(1), 63-74.

24. Brown, G. (2004). 'Brand Loyalty- Factor Fiction', Advertising Age, Journal of Marketing Theory and Practice, 53-55.

25. Bruner, M. (2000). R Marketing. Indianapolis, IN. New Riders Publishing, Best Practices for Web.

26. Bryman, A. \& Bell, E. (2007). Writing up business research. In: Business Research Methods. New York. Oxford University Press. P. 691-723.

27. C. Lagarde, Decisive Action to Secure Durable Growth, Bundesbank and Goethe University Frankfurt, Germany, 2016. April 5, 2016. Retrieved on 29th January, 2018 from https://www.imf.org/en/News/Articles/2015/09/28/04/ $53 / \mathrm{sp} 040516$.

28. Cadogan, A. \& Foster, W. (2000). Investigation, Marketing Intelligence and Planning, 18(4), 185-199. 
29. Cadogan, J.W. \& Foster, B.D. (2000). Relationship Selling and Customer Loyalty: An Empirical Investigation, Marketing Intelligence and Planning, 18(4), 185-199.

30. Chandon, P., Wansink, B. \& Laurent, G. (2000). "A benefit congruency framework of sales promotion effectiveness", Journal of Marketing Theory and Practice, 63-101.

31. Chaudhuri, A. \& Holbrook, M.B. (2001). 'The Chain of Effects from Brand Trust and Brand Affect to Brand Performance: The role of Brand Loyalty, Journal of Marketing 15(2), 81-94.

32. Circa 2000 B.C, Management International Review, 38 (2), 95-107.

33. Clow, M. (2010). Integrated Marketing Communications. Pearson Education, Inc. publishing as Prentice Hall.

34. Coman, A., and Ronen, B. (2009). Focused SWOT: diagnosing critical strengths and weaknesses. International Journal of Production Research, 47(20).

35. Cronin, J., Jr., Brady, M., \& Hult, T. (2000). Assessing the effects of quality, value, and customer satisfaction on consumer behavioral intentions in service environments. Journal of Retailing, 76(2), 193-218

36. Cseres, K. J. (2005). Competition law and consumer protection (Vol. 49). Kluwer Law International BV.

37. Davis. J.A. (1971). Elementary survey analvsis. Englewood, NJ: Prentice-Hall.

38. Department of Statistics, Malaysia. (2010). Population and Housing Census of

39. De Ruyter, K., Wetzels, M., \& Van Birgelen, M. (1999). How Do Customers React to Critical Service Encounters: A Cross-sectional Perspective. Total Quality Management, 10(8), 1131-1145

40. Eduardo. Z. (2008).Customer satisfaction and loyalty: start with the product, culminate with the brand, Journal of Consumer Marketing, 25(5) $302-31$

41. Elseidi, R. I. (2018). Determinants of halal purchasing intentions: evidences from UK. Journal of Islamic Marketing.

42. Ergin, E.A. (2005). Brand Loyalty İn The Cosmetics Industry: Field Study On Turkish Womenees Brand Loyalty Among Cosmetics Products. Journal of Business \& Economics Research, 12-35

43. Gardial, S. F., Clemons, D. S., Woodruff, R. B., Schumann, D. W., \& Burns, M. J. (1994).Comparing consumer's recall of pre-purchase and post purchase product evaluation experiences. Journal of Consumer Research, 20(2), 548560

44. Gerpott, D.A, Rams, M.A, \& Schindler, B.K, (2011). Technology Infusion in service encounters. Academy of Marketing Science Journal, 28(1), 138-149.

45. Global Retail Development Index. (2019). The Age of Focus. Retrieved from Atkearney: https://www.atkearney.com/global-retail-development-index/ranking

46. Gundlach, G. T. (2007). The American Marketing Association's 2004 definition of marketing: Perspectives on its implications for scholarship and the role and responsibility of marketing in society. Journal of Public policy \& marketing, 26(2), 243-250.

47. Hamza, S. (2011). The Influence of Brand Loyalty on Cosmetics Buying Behavior of UAE Female Consumers. Journal

International of Marketing Studies, 3(2), 30-67.

48. Hassali, M.A. (2015). Malaysian cosmetic market: current and future prospects. Retrieved from http://www.omicsgroup.org/journals/malaysian-cosmetic-market-current-and-future-prospects-2167-76891000155.php?aid=65405

49. Heim, G. R., \& Sinha, K. K. (2001). Operational Drivers of Customer Loyalty in Electronic Retailing: An Empirical Analysis of Electronic Food Retailers. Manufacturing \& Service Operations Management, 3(3), 264271. doi:10.1287/msom.3.3.264.9890

50. Inamullah, K. (2012). Impact of Customers Satisfaction and Customers Retention on Customer Loyalty. International Journal of Scientific \& Technology Research 1(2) 106-110

51. Ismail, B, Tajuddin, M.T, Armia, R.N, Samsudin, M.M, Zain, R.A and Derani, N. (2012). The relationship between store brand and customer loyalty in retailing in Malaysia. Asian Social Science, 
52. Italian Trade Agency. (2011). Italian Trade Agency. Retrieved from Italian Trade Commision:http://www.ice.gov.it/paesi/asia/malaysia/upload/173/MALAYSIA

53. Katz, M. \& Daniel, N. (1960). The functional approach to the study of attitudes, Public Opinion Quarterly, 1960, 24, 163-204

54. Keller, K. L. (2003). Strategic Brand Management: Building, Measuring and Managing Brand Equity. New Jersey: Prentice Hall

55. Keller, K.L. (2007). Strategic Brand Management: Building, Measuring and Managing Brand Equity. New Jersey: Prentice- Hall Inc.

56. Khan, S. \& Noor, F. (2012)" Factors affecting buying behavior of females for purchase of cosmetics" International review of business and social sciences 1(9), 68-76.

57. Kleine, O.M., Susan. P., Robert, E., Kernan, M., \& Jerome, B. (1993). Mundane Consumption and the Self: A SocialIdentity Perspective," Journal of Consumer Psychology, 2 (3), 209-235.

58. Kohli, C., \& Thakor, M. (1997) Branding consumer goods: Insights from theory and practice. Journal of Consumer Marketing, 14, 206-219.

59. Kotler, P. \& Lane, K. (2007). Marketing Management, Pearson International Edition . 2007

60. Kotler, P. (2010), Marketing Management: Analysis, Planning, Implementation and Control, 8th Edition.

61. Kotler, P., Armstrong, G., Saunders, J., \& Wong, V. (1999). Principles of Marketing (Second European Edition ed.). Upper Sadle River: Prentice Hall Inc.

62. Kottler, D.L. (2003). The evolution of customer loyalty strategy. The Journal of Consumer Marketing, 22(5), $284-286$.

63. Lawrence, R.J. (2011). Patterns of Buyer Behaviour Time for a new approach. Journal of marketing Research 137144.

64. Lin, A., \& Wu, K. (2011). The pool is drying up. Marketing Research, 10(1), 26-32. Leewichi, N. \& Bunker, J.W. (1995). Relationship selling and customer loyalty: an empirical investigation. Marketing Intelligence and Planning, $18(4), 185$.

65. Low, S. (2017). The rising demand for halal cosmetics. Retrieved from The Star: https://www.thestar.com.my/lifestyle/style/2017/10/13/rising-demand-halal-cosmetics/

66. Luk, S. T., \& Yip, L. S. (2008). The moderator effect of monetary sales promotion on the relationship between brand trust and purchase behaviour. Journal of Brand Management, 15(6), 452-464.

67. Malaysia. Retrieved from http://www.statistics.gov.my/portal/download Population/files/population/04J adual_PBT_negeri/PBT_Selangor.pdf. Last accessed 15 October 2014.

68. Malhotra, N.K. (2004). Measurement and scaling: Non comparative scaling techniques. In Marketing Research: An Applied Orientation (6th ed., Vols. 270-295). Upper Saddle River: Pearson Prentice Hall.

69. Mansor, N. (2010). Cosmetic Usage in Malaysia: Understanding of the Major Determinants Affecting. International Journal of Business and Social Science ,273-281.

70. Mintz, J. (2014). Why the TOWS Matrix is important to Public

71. Moore, C., Karl, M., Lewis, M. \& David, K. (1998). The First Multinationals: Assyria

72. Morgan, R. M. \& Hunt, S. D. (1994). The commitment-trust theory of relationship marketing. Journal of Marketing, 58(3), 20-38.

73. Mugenda O.M., Mugenda A.G. (2003). Research Methods: Quantitative and Qualitative approaches. Nairobi: ACIS press.

74. Nadome, A. (2014). Spending Habits among Malaysian University Students. 1-21. Lovelock, C. H. (2010). Services Marketing, (4th ed), New Jersey: Prentice Hall.

75. NG, A. (2013). Business: The Star Online. Retrieved from The Star Online.

76. Ngah, A. H., \& Thurasamy, R. (2018). Modelling the intention to adopt halal transportation among halal pharmaceutical and cosmetic manufacturers in Malaysia. Advanced Science Letters, 24(1), 205-207.

77. O'Brien, L. \& Jones, C. (1995). Do rewards really create loyalty? Harvard Business Review, 75-83. 
78. Oliver, K. \& Swan, J. E. (1989) Consumer Perceptions of Interpersonal Equity and Satisfaction in Transactions: A Field Survey Approach. Journal of Marketing, 58(2), 21-35.

79. Oliver, R New York..L,( 1997). Satisfaction: A Behavioural Perspective on the .Consumer, McGraw-Hill.

80. Oliver, R. \& Rust, R. (1997) Customer Delight: Foundations, Findings, and Managerial Insight, Journal of Retailing, 73 (3), 311-337.

81. Oliver, R.L. (2011), " Whence customer loyalty?" Journal of Marketing, 63, 33-44.

82. Oliver, R.L., \& DeSarbo, W.S., (1988). Response determinants in satisfaction judgments, Journal of Consumer Research, 14, 495-508.

83. O'Malley, K. (2014). Cosmetic Manufacturing in Ireland. Retrieved November 30, 2015, from http://cosmeticsireland.com/

84. Omanga, L. (2010). Determinants Of Brand Loyalty In Cosmetic Products: A Case Of Selected Salons In Nyeri Town, $1-98$

85. Pallant, J. (2011). SPSS SURVIVAL MANUAL A step by step guide to data analysis using SPSS (4th edt). Crows Nest. New South Wales: Allen \& Unwin

86. Pallant, J. (2013). SPSS Survival Manual: A Step By Step Guide To Data Analysis

87. Parasuraman, A. (1980). A Conceptual Model of Service Quality and Its Implication for Future Research. Journal of Marketing, 49, 41-50

88. Parasuraman, A., \& Grewal, D. (2000). The impact of technology on the quality-value- loyalty chain: A research agenda. Journal of the Academy of Marketing Science, 28(1), 168-174.

89. Parmar, S. M. (2014). A Study of Brand Loyalty for Cosmetic. Journal for Research in Management and Pharmacy,3(6), 26-36

90. Pearson, K. (1908). On the generalized probable error in multiple normal. correlation. Biometrika, 6, 59-68

91. Ravald, A., \& Gronroos, C. (1996). The value concept and relationship marketing. European Journal of Marketing, 30(2), 19-30.

92. Region, Global Journal of Management and Business Studies, 3( 7 ), 817-824.Stevens, J. (1996). Applied multivariate statistics for The social sciences (3rd edn).Mahwah, NJ: Lawrence Erlbaum

93. Reichheld, F. F., \& Sasser, W. E. Jr. (1990). Zero defections: Quality comes to services, Harvard Business Review, 105-111.

94. Rice, G. (1999). Islamic ethics and the implications for business. Journal of business ethics, 18(4), 345-358.

95. Rizwan, A. ( 2013). The Impact of the Perceived Quality, Customer Satisfaction, .Brand Trust and Contextual Factors on Brand Loyalty, International Journal of Research in Commerce and Management, 4(3), 83-89.

96. Roscoe, J.T. (1975) Fundamental Research Statistics for the Behavioural Sciences, 2nd edition. New York: Holt Rinehart \& Winston.

97. Rosenberg, L., Czepiel, J.A. (1984) Marketing Approach to Customer Retention. Journal of Consumer Marketing, 1 (2), 45-51.

98. Saleem, A., Ghafar, A., Ibrahim, M., Yousuf, M., \& Ahmed,N. (2015). Product perceived quality and purchase intention

99. with consumer satisfaction. Global journal of management and business research.

100.Schiffman, L.G. and Kanuk, L.L. (2008), Consumer Behaviour, $6^{\text {th }}$ edition, New Jersey: Prentice Hall Inc.

101.Schindler, R.M. (1998). Consequences of perceiving oneself as responsible for obtaining a discount: evidence for smart-shopper feelings", Journal of Consumer Psychology, 7 (4).371-392. 